\title{
Amphibolite-Hosted Fe-Ti Oxide Mineralization of the Mitrashinci Deposit, Eastern Macedonia
}

\author{
O. Spasovski ${ }^{a}$, A. V. Volkov ${ }^{b}$, T. Serafimovski ${ }^{a}$, and B. Boev ${ }^{a}$ \\ ${ }^{a}$ Faculty of Mining and Geology, Goce Delcev University, Stip, Republic of Macedonia \\ ${ }^{b}$ Institute of Geology of Ore Deposits, Russian Academy of Sciences, Staromonetnyi per. 35, Moscow, 119017 Russia
}

Received June 17, 2014

\begin{abstract}
The Mitrashinci deposit in Eastern Macedonia represents a unique type of metamorphosed FeTi deposits. Fe-Ti oxide mineralization was identified in amphibolites from the metamorphic complex of the Serbo-Macedonian massif, which comprise two different stratigraphic horizons striking NW-SE. At Mitrashinci, Fe-Ti oxide mineralization is hosted by deeply buried amphibolites of the second stratigraphic horizon. Two types of amphibolites were recognized, almost barren garnet-biotite and mineralized garnetcummingtonite. The mineralized zone (varying in thickness from 20 to $300 \mathrm{~m}$ ) has been traced for $12 \mathrm{~km}$ within amphibolite host rocks. Several lens-like ore bodies hosted by garnet-cummingtonite amphibolites striking NW-SE have been intersected by mining operations at Kobilski Rid, Gromadna, Leskovica, Dolga Poljana, and Bliznakov Cukar. The contents of Fe and Ti vary greatly in the ores (13-23\% and 4-9.1\%, respectively). The ore bodies consist mainly of $\mathrm{Fe}-\mathrm{Ti}$ oxides, such as magnetite, titanomagnetite, ilmenite, and hematite (martite), and minor pyrite, chalcopyrite, pyrrhotite, rutile, titanite, leucoxene, and goethite. The major ore minerals (ilmenite, titanomagnetite, and magnetite with a minor sulfide phase) were formed during the magmatic phase of ore deposition and were not considerably affected by subsequent polyphase metamorphism.
\end{abstract}

DOI: $10.1134 / \mathrm{S} 107570151503006 \mathrm{X}$

\section{INTRODUCTION}

Numerous occurrences of $\mathrm{Fe}-\mathrm{Ti}$ mineralization in the eastern part of the Serbo-Macedonian massif (SMM) were first discovered in 1957. After several decades of systematic research on the metamorphic complexes and $\mathrm{Fe}-\mathrm{Ti}$ mineralization of the massif, the results were reported in many previous publications (Simic, Simic, 1957, 1963; Ivanov, 1975; Jovanovis, Kuvenxiski, 1977, 1980; Dumurxanov, 1977，1978; Dumurxanov et al., 1978; Spasovski, 1993, 1994, 2001, 2004; Serafimovski, Spasovski, 1994; Spasovski, Serafimovski, 1998; Mircovski et al., 1996; Petkovski et al., 1997; Stojanov et al., 1997). Detailed prospecting and sediment sampling was carried out in the most prospective area of the Mitrashinci deposit.

Representative samples of ore material and bedrocks were collected from surface outcrops, trenches, and pits at the Mitrashinci deposit during fieldwork conducted periodically between 1993 and 2013 by researchers from the Faculty of Mining and Geology at Goce Delcev University (Macedonia). As a result of this work, detailed geological maps, plans, sketches, and cross sections were compiled. The samples were subjected to petrographic, petrochemical, mineralogical, and geochemical analyses.

Corresponding author: A.V. Volkov. E-mail: alexandr@igem.ru
The goal of this study is to summarize the results obtained over more than 20 years of study of $\mathrm{Fe}-\mathrm{Ti}$ oxide mineralization at the Mitrashinci deposit. It should be noted that the Mitrashinci Fe-Ti deposit represents a metamorphosed type of deposits, which has not been studied in any detail either in Russia or other countries worldwide.

\section{GEOLOGICAL FRAMEWORK}

The Mitrashinci deposit is situated in the eastern part of the SMM near the town of Berovo (Fig. 1). The SMM is a crystalline (cratonic) terrane bordering the Carpathian-Balkanides in northeast and the Vardar ophiolitic zone in the southwest (Fig. 1). The SMM comprises two structural levels, which are composed of metamorphic rocks of different ages. The Macedonian part of the massif is dominated by Lower Proterozoic complexes containing amphibolites, which occur at two different stratigraphic horizons trending NW-SE. This polymetamorphic and polydeformational complex consists of two mica and biotite gneisses, migmatites, quartz-feldspathic gneisses, quartzites, and amphibolites that developed after mafic and ultramafic rocks (Fig. 2). These rocks underwent at least two regional metamorphic events, the earlier one at about $1.0 \mathrm{Ga}$ and the major one at 530-550 Ma (Zagorchev, Moorbath, 1986), followed by the emplacement of 
Hercynian granites and intense Alpine folding as a result of which the SMM crystalline slices became thrust over adjacent tectonic blocks. Geological evidence suggests that amphibolite-facies regional metamorphism was post-Precambrian in age. The amphibolites of the SMM represent two separate stratigraphic horizons, composed of barren and underlying mineralized amphibolites. At Mitrashinci, Fe-Ti oxide mineralization is hosted in deeply buried amphibolite horizons.

The mineralized amphibolites have a present strike length of about $12 \mathrm{~km}$, of which only $5 \mathrm{~km}$ were explored in detail in the northwestern part (Fig. 3). The thickness of the horizon varies in places (from 20 to $300 \mathrm{~m}$ ) along strike and down dip. Just southwest of Mitrashinci at Cungovec-Kasaplija, amphibolites form several thick lenses with $\mathrm{Fe}-\mathrm{Ti}$ oxide mineralization.

Macroscopic and microscopic examination reveals two types of amphibolites present at the Mitrashinci deposit: ore-bearing garnet-cummingtonite amphibolites with $\mathrm{Fe}$-Ti oxide mineralization and barren garnet-biotite amphibolites. The chemical and mineral compositions of amphibolites of both types are given in Tables 1 and 2.

Garnet-biotite amphibolites are dark green, medium- to coarse-grained (over $2 \mathrm{~mm}$ across) with a massive to weakly foliated porphyroblastic texture. They contain minor amounts of Fe-Ti oxides (Table 1) and host extensive lenses of ore-bearing garnet-cummingtonite amphibolites. Garnet-biotite amphibolites are composed of hornblende, garnet, biotite, albite, epidote, chlorite, quartz, apatite, magnetite, and ilmenite.

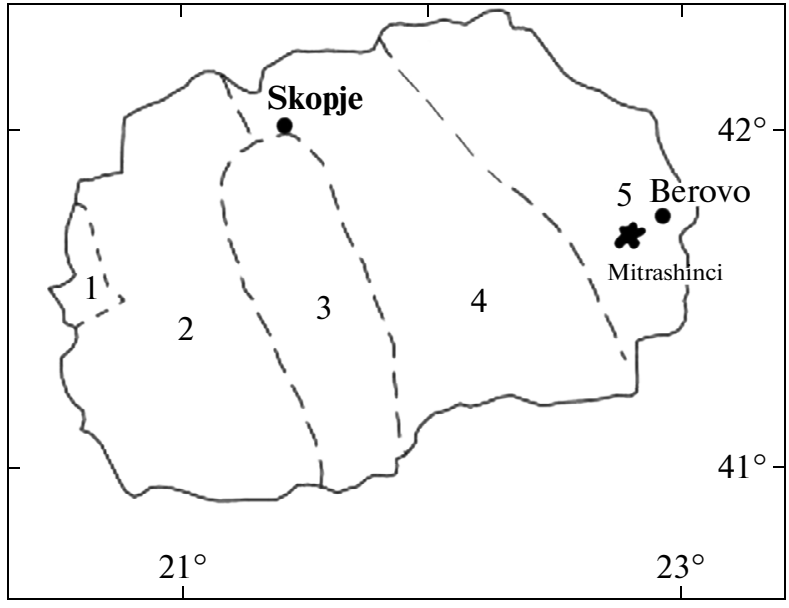

Fig. 1. Location of the Mitrashinci deposit. The numbers on the map denote tectonic zones and structures after Dumurdzanov et al. (2005):

1-Pindos; 2-Pelagonian; 3-Pelagonian antiform; 4-Vardar; 5-Serbo-Macedonian (SMM).

As noted above, garnet-cummingtonite amphibolites (Fig. 4) have high Fe-Ti oxide contents (Table 1) and are dark grey porphyroblastic and massive rocks composed of cummingtonite, garnet, hornblende, magnetite, titanomagnetite, ilmenite, biotite, quartz, sometimes hematite. Ore minerals are common or may dominate a rock composition.

As seen in Table 1, both types of amphibolites have strikingly different compositions. Moreover, analyses indicate notable compositional variation within the same type of amphibolite (Table 1). The largest difference is that the garnet-cummingtonite amphibolites

Table 1. Chemical composition of amphibolites from the Mitrashinci deposit (wt \%)

\begin{tabular}{|c|c|c|c|c|c|c|c|c|}
\hline Sample/component & M-4* & M-6* & M-18* & M-19* & M-8** & M-9** & M-10** & M-13** \\
\hline $\mathrm{SiO}_{2}$ & 37.90 & 40.26 & 14.40 & 14.80 & 43.56 & 46.0 & 50.15 & 46.77 \\
\hline $\mathrm{TiO}_{2}$ & 3.20 & 5.60 & 12.50 & 12.50 & 5.73 & 2.60 & 1.50 & 3.60 \\
\hline $\mathrm{AI}_{2} \mathrm{O}_{3}$ & 3.68 & 5.54 & 3.69 & 3.10 & 16.30 & 12.05 & 15.70 & 10.70 \\
\hline $\mathrm{Fe}_{2} \mathrm{O}_{3}$ & 14.78 & 11.76 & 30.96 & 32.21 & 6.10 & 4.91 & 2.47 & 6.23 \\
\hline $\mathrm{FeO}$ & 26.35 & 20.60 & 29.44 & 28.79 & 13.66 & 16.72 & 7.82 & 12.52 \\
\hline $\mathrm{MnO}$ & 2.11 & 1.36 & 0.73 & 1.07 & 0.61 & 1.02 & $0.1 \mathrm{~S}$ & 1.10 \\
\hline $\mathrm{MgO}$ & 6.47 & 5.05 & 2.40 & 1.97 & 1.41 & 4.70 & 6.16 & 3.12 \\
\hline $\mathrm{CaO}$ & 3.11 & 6.57 & 2.4 & 2.19 & 6.05 & 6.06 & 9.97 & 9.37 \\
\hline $\mathrm{Na}_{2} \mathrm{O}$ & 0.21 & 0.92 & 0.34 & 0.28 & 4.73 & 2.78 & 3.45 & 2.40 \\
\hline $\mathrm{K}_{2} \mathrm{O}$ & 0.13 & 0.29 & $0.4 \mathrm{~S}$ & 0.76 & 0.29 & 0.90 & 0.87 & 0.53 \\
\hline $\mathrm{P}_{2} \mathrm{O}_{5}$ & 0.30 & 0.27 & 0.49 & 0.29 & 0.26 & 1.09 & 0.19 & 1.93 \\
\hline $\mathrm{H}_{2} \mathrm{O}^{+}$ & 1.40 & 1.58 & 1.67 & 1.68 & 1.28 & 1.41 & 1.52 & 1.88 \\
\hline $\mathrm{H}_{2} \mathrm{O}^{-}$ & 0.11 & 0.15 & 0.04 & 0.06 & 0.16 & 0.05 & 0.11 & 0.14 \\
\hline Total & 99.74 & 100.24 & 99.86 & 99.70 & 100.14 & 100.15 & 99.89 & 100.29 \\
\hline
\end{tabular}

XRF. Samples: * garnet-cummingtonite amphibolite and ** garnet-biotite amphibolite. 


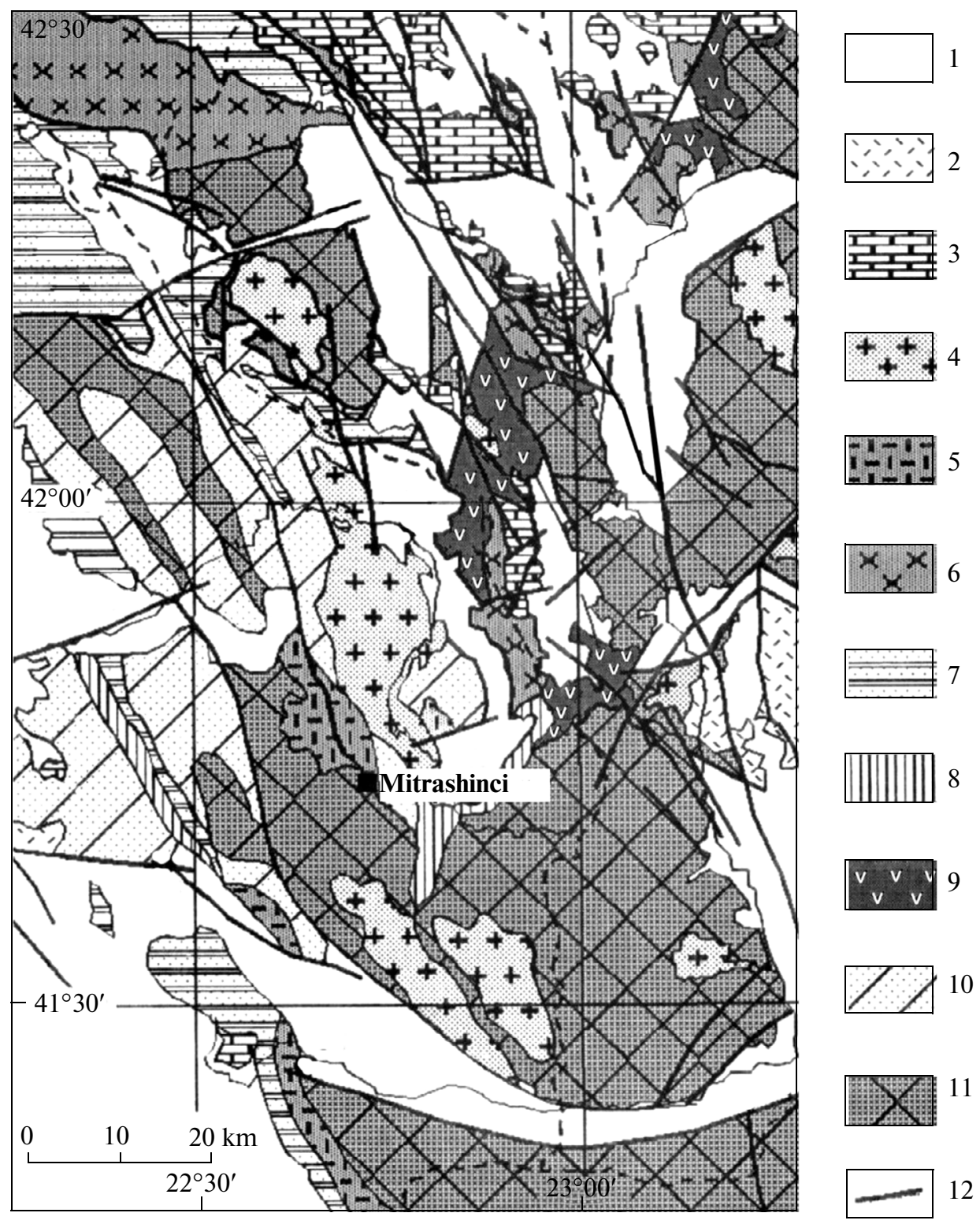

Fig. 2. Geological sketch map showing the border regions of Macedonia and Bulgaria and the location of the Mitrashinci deposit. The tectonic map is modified after Stojanov et al. (1997).

1-Tertiary and Quaternary deposits; 2-Mesozoic granites; 3-Mesozoic limestones; 4-Paleozoic granitoids; 5-Paleozoic quartz porphyries; 6-Paleozoic diorites; 7-Silurian-Devonian deposits; 8-Lower Paleozoic rocks; 9-diabase-phyllite unit; 10-Precambrian and/or Paleozoic mica schists; 11-Precambrian high-grade metamorphic complex; 12-faults and thrusts.

have lower $\mathrm{SiO}_{2}, \mathrm{Al}_{2} \mathrm{O}_{3}, \mathrm{Na}_{2} \mathrm{O}$ and $\mathrm{CaO}$ and higher $\mathrm{FeO}, \mathrm{Fe}_{2} \mathrm{O}_{3}$, and $\mathrm{TiO}_{2}$ compared to garnet-biotite amphibolites (Table 1).

As seen in Table 1, two petrochemical types of amphibolites can be distinguished: $\mathrm{Fe}-\mathrm{Ti}$ amphibolites, with 32.6-60.4\% $\left(\mathrm{FeO}+\mathrm{F}_{2} \mathrm{O}_{3}\right)$ and 5.73$12.50 \% \mathrm{TiO}_{2}$, and $\mathrm{Al}-\mathrm{Na}$ amphibolites, with low $\mathrm{Al}_{2} \mathrm{O}_{3}$ and $\mathrm{Na}_{2} \mathrm{O}_{3}$ of $10.70-16.30 \%$ and $2.40-4.73 \%$, respectively, and $10.29-21.63 \%\left(\mathrm{FeO}+\mathrm{Fe}_{2} \mathrm{O}_{3}\right)$ and 1.5$5.60 \% \mathrm{TiO}_{2}$ (Table 1).
The chemical composition of amphibolites suggests their derivation from mafic igneous rocks enriched in $\mathrm{Fe}$ and $\mathrm{Ti}$, and the differences in their chemical composition are probably the result of the primary composition of igneous rocks and element redistribution during regional metamorphism.

Morphology of ore bodies. Geological exploration at Mitrashinci revealed several lens-like ore bodies variable in size that dip $50^{\circ}-60^{\circ} \mathrm{NW}-\mathrm{SE}$ (Figs. 3 and 5).

The largest ore body $(500 \times 100 \times 30 \mathrm{~m})$ was discovered and explored at Kobilski Rid (Fig. 5a) with esti- 


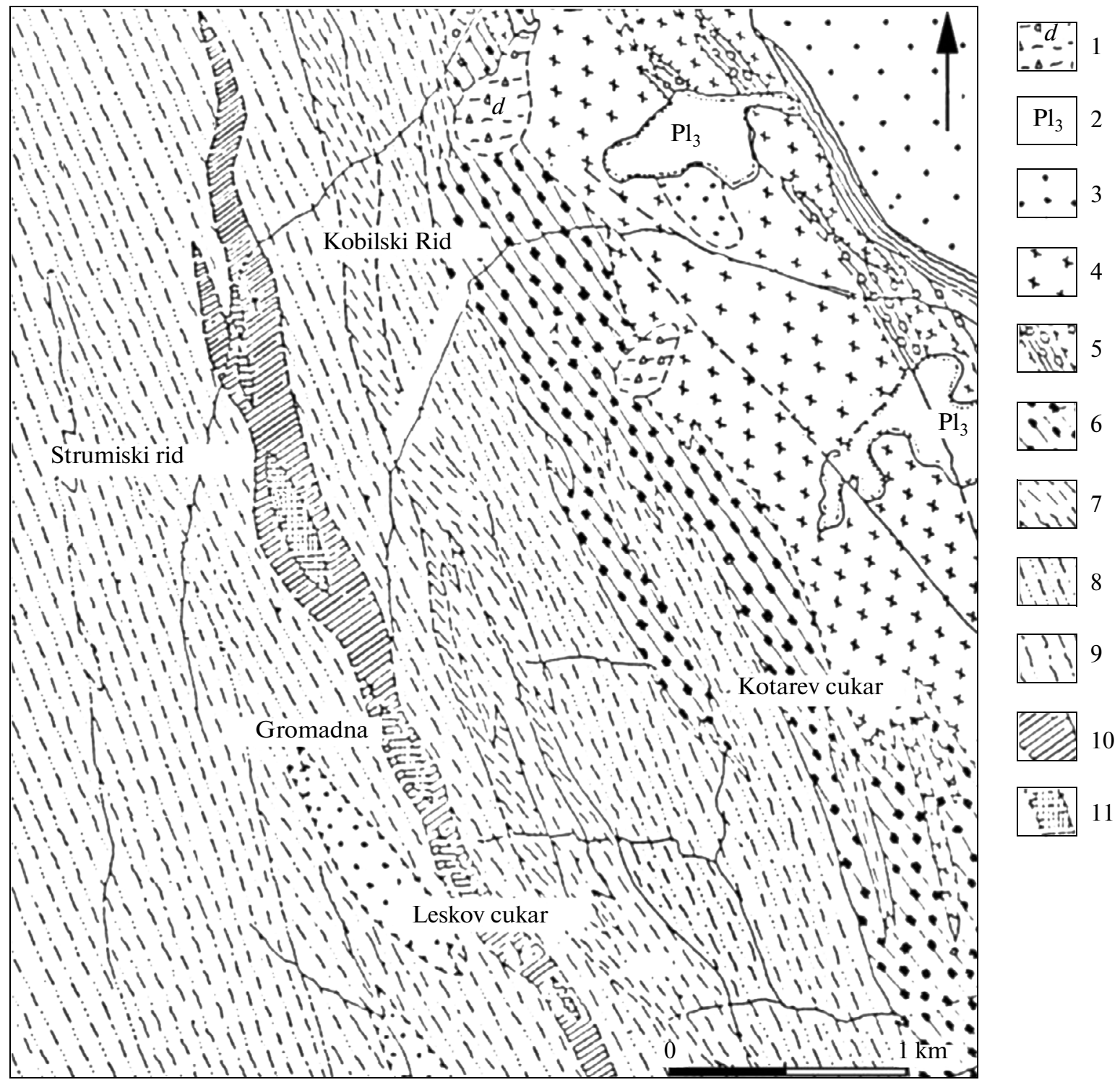

Fig. 3. Geological map of the study area, modified after Spasovski (2001).

1-talus; 2-Pliocene deposits; 3-massive biotite granite; 4-schistose granite; 5-quartz-chlorite-sericite schist; 6amphibolite-chlorite schist; 7-mica schist; 8-lenticular two-mica gneiss; 9—lenticular muscovite gneiss; 10—weakly mineralized garnet amphibolite; 11—garnet amphibolite with high $\mathrm{Fe}-\mathrm{Ti}$ oxide content (Mitrashinci ore zone).

mated reserves of about 4.5 million tons of ore at $13 \%$ $\mathrm{Fe}$ and $4 \% \mathrm{TiO}_{2}$. In addition to Kobilski Rid, ode bodies were identified at several other localities (from NW to SE along the strike of the ore zone): Gromadna, Leskovica, Dolga Poljana, and Bliznakov Cukar (Fig. 3).

The Gromadna ore body ranges in thickness from 8.7 to $33.0 \mathrm{~m}$ (Fig. 5b) and has $\mathrm{Fe}$ and $\mathrm{TiO}_{2}$ contents of 14.03-22.93 wt \% and 6.95-9.1 wt \%, respectively. The Leskov Cukar ore body ranges in thickness from 14.80 to $31.80 \mathrm{~m}$ (Fig. $5 \mathrm{c}$ ) and has $\mathrm{Fe}$ and $\mathrm{TiO}_{2}$ contents of 15.01-22.30 wt \% and 4.50-9.0 wt \%, respectively. All of the above ore bodies are generally similar in their morphology (Fig. 5).

\section{MINERALOGY AND GEOCHEMISTRY OF ORES}

The mineralogy, paragenetic relationships, and ore types at Mitrashinci have been described in detail in many previous papers (Simic, Simic, 1963; Dumurxanov, 1978; Spasovski, 1993, 1994, 1997, 2001, 2004). Based on previous data and results from our study, the following minerals have been identified in ores: ilmenite, titanomagnetite, magnetite, pyrite, pyrrhotite, chalcopyrite, cubanite, arsenopyrite, pentlandite, hematite-martite, hematite-specularite, titanite, rutile, anatase, leucoxene, coulsonite, limonite, goethite, and lepidocrocite. 
Table 2. Quantitative mineralogical analysis of garnet-cummingtonite amphibolites from the Mitrashinci deposit

\begin{tabular}{l|c|c|c}
\hline \multirow{2}{*}{\multicolumn{1}{c|}{ Mineral }} & \multicolumn{3}{c}{ Content (\%) } \\
\cline { 2 - 4 } & PI/1 & R-10 & SR-81 \\
\hline Hornblende + cummingtonite & 49 & 59 & 58 \\
Hornblende & & 42 & \\
Cummingtonite & & 17 & \\
Chlorite & 13 & 14 & 12 \\
Magnetite & 12 & 7 & \\
Palygorskite & 10 & & 12 \\
Quartz & 10 & 11 & \\
Albite & & & 12 \\
Garnet-spessartine & 5 & 8 & 5 \\
\hline
\end{tabular}

Mineralogical analysis was performed at the Goce Delcev University, Stip, Republic of Macedonia

The major ore minerals are ilmenite, titanomagnetite, and magnetite. The content of $\mathrm{Fe}-\mathrm{Ti}$ oxides in ores varies from 50 to $80 \%$ and higher. Accessory minerals occur in minor amounts $(1-3 \%)$ and include pyrrhotite, chalcopyrite, pyrite, hematite, etc.

Below we present the mineralogical and geochemical data for major ore minerals, which can be used for further genetic reconstructions.

The major oxides and trace elements in host rocks were analyzed by X-ray fluorescence using a VRA-20 instrument at the RSA Laboratory of the Institute of Geology and Geophysics (Sofia). Some samples were analyzed using a JEOL JSM 35 CF scanning electron microscope equipped with an X-TractorNorthern TN-2000 microanalyzer at the Institute of Photoprocesses (Bulgaria). Other samples of $\mathrm{Fe}-\mathrm{Ti}$ ores were analyzed using a JEOL 733 SuperProbe analyzer

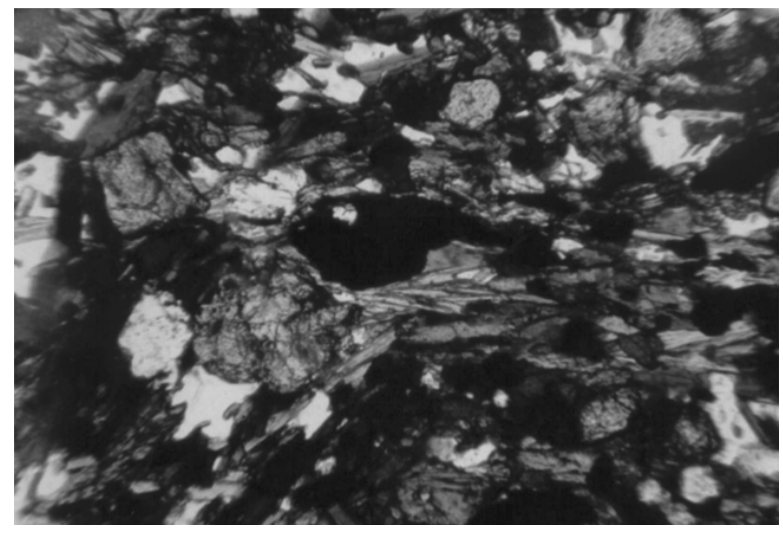

Fig. 4. Garnet-cummingtonite amphibolite, Kobilski Rid ore body, Mitrashinci deposit. Black grains are $\mathrm{Fe}-\mathrm{Ti}$ oxide minerals, magnetite and titanomagnetite (parallel nicols, $30 \times$ magnification). equipped with an EDS system at the Institute of Geology (Bratislava). Instrument detection limits for all elements were $0.01 \mathrm{wt} \%$. Monomineralic fractions of pyrite were analyzed by atomic absorption spectrometry.

Magnetite is commonly present as pure $\mathrm{Fe}_{2} \mathrm{O}_{4}$, titanomagnetite $\mathrm{Fe}(\mathrm{Fe}, \mathrm{Ti})_{2} \mathrm{O}_{4}$ or high-temperature Tirich magnetite. A decrease in temperature causes exsolution processes leading to the formation of ilmenite exsolution lamellae or discs (Fig. 6a), with lamellar thicknesses of 5-40 $\mu \mathrm{m}$. Some magnetite grains are partially (from rim to core) or completely martitized. The martitization is only present at the peripheral parts of magnetite grains (Fig. 6c). The magnetite crystalline lattice is favorable for isomorphic inclusion of a large number of elements (Tables 3 , 4). The number and concentrations of trace elements in magnetite from intrusive rocks depend on the type of the magmatic ore-forming process. The analysis of monomineralic samples of magnetite ores showed that they contain 47-57 ppm Ni, 360-932 ppm Mn, 15$61 \mathrm{ppm} \mathrm{Cu}, 2-3 \mathrm{ppm} \mathrm{Ag}, 5-8 \mathrm{ppm} \mathrm{Cd}, 30-70 \mathrm{ppm}$ $\mathrm{Bi}, 6-11 \mathrm{ppm}$ In (Table 3 ). High-grade ores may consist of up to $45-50 \%$ and on the average $10-15 \%$ magnetite (Table 2).

The chemical analysis of single grains and monomineralic fractions indicated very low trace element contents of magnetite, which have little or no effect on the genetic characteristics of magnetite. The following trace elements were identified in the crystalline structure of magnetite: $\mathrm{Cr}, \mathrm{Ti}, \mathrm{V}, \mathrm{Mn}, \mathrm{Ni}, \mathrm{Co}, \mathrm{Zn}, \mathrm{Mg}, \mathrm{Si}$, $\mathrm{Ca}$, and $\mathrm{Al}$. These are generally present as isomorphic structural admixtures, substituting $\mathrm{Fe}^{2+}$ and rarely $\mathrm{Fe}^{3+} . \mathrm{Fe}^{2+}$ is substituted by $\mathrm{Mn}, \mathrm{Mg}, \mathrm{Ni}, \mathrm{Co}, \mathrm{Zn}$, and $\mathrm{Ca}$, while $\mathrm{Fe}^{3+}$ is substituted by $\mathrm{Ti}, \mathrm{V}, \mathrm{Cr}, \mathrm{Al}$, and $\mathrm{Si}$. The content of trace elements, especially $\mathrm{Cr}, \mathrm{Ti}$, and $\mathrm{Ni}$, in the analyzed samples of magnetite (Table 4) is the typomorphic feature suggesting a genetic link between mineralization and magmas of different petrochemical compositions. In addition, trace-element analysis allows a conclusion about the composition of the crystallization medium due to the ability of magnetite to absorb typomorphic trace elements from the medium during deposition.

Table 4 shows that all of the magnetite grains have almost identical chemical composition of $74 \% \mathrm{Fe}$, $0.05-0.36 \% \mathrm{Ti}, 0.36-0.52 \% \mathrm{Ni}, 0.03-0.04 \% \mathrm{Cr}$, and $0.08-0.09 \% \mathrm{Mn}$ (Table 4). The same is true for titanomagnetite.

Ilmenite is a common mineral occurring as aggregates with complex isometric shapes (Fig. 6b). The amount of ilmenite in high-grade ores may reach 15$20 \%$, being on average 5-7\%. Intergrowths of ilmenite with magnetite and titanomagnetite show a distinct mosaic pattern. The grains of pure ilmenite are found intergrown with rare thin hematite laths (exsolution textures). Ilmenite contains drop-like inclusions of pyrrhotite. Ilmenite commonly forms lamellae in 

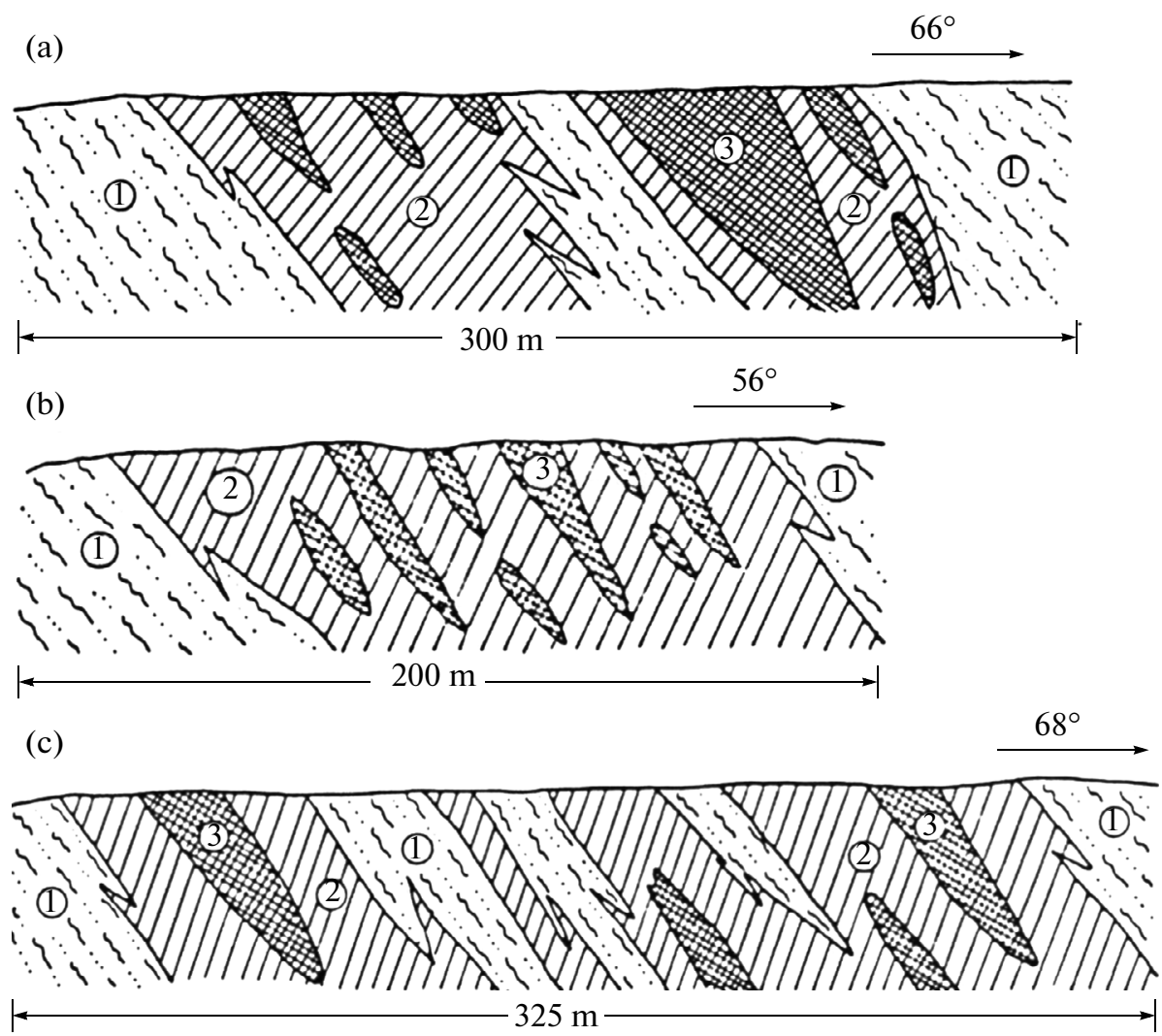

Fig. 5. Cross sections across the strike of the ore zone at localities of the Mitrashinci deposit: (a), Kobilski Rid, (b), Gromadna, (c), Dolga Poljana (see Fig. 3).

1-gneiss; 2 -weakly mineralized amphibolites $(\mathrm{Fe}<10 \%) ; 3$-ore bodies with high concentrations of Fe-Ti oxide minerals $(\mathrm{Fe}>10 \%)$.

magnetite and titanomagnetite aggregates (Fig. 6c). A distinctive feature of ilmenite from the Mitrashinci ores is its high purity (Table 5). Ilmenite contains only minor amounts of admixtures, such as $0.18-0.34 \%$ $\mathrm{Ni}, 0.23-0.38 \% \mathrm{Al}, 0.05-0.11 \% \mathrm{Cr}, 0.29 \% \mathrm{Mg}, 1.74-$ $2.21 \% \mathrm{Mn}$, etc.

Hematite occurs as idiomorphic or hypidiomorphic acicular aggregates, often intersecting each other. The amount of hematite in ores does not exceed 3\%. Some hematite grains exhibit cellular textures resulting from martitization of magnetite.

Pyrite is common but not very abundant (about 1\%). It is present as inclusions in magnetite or irregularly dispersed in the host rocks. Pyrite grains are developed along cleavage directions. As seen in Table 6, pyrite is characterized by wide variations in $\mathrm{Ni}, \mathrm{Co}$, and $\mathrm{Cu}$

Table 3. Trace element composition of magnetites from the Mitrashinci deposit (ppm)

\begin{tabular}{l|c|c|c|c|c|r|r}
\hline \multicolumn{1}{c|}{ Element } & 1 & 2 & 3 & 4 & 5 & 6 & 7 \\
\hline $\mathrm{Fe} \%$ & 61.81 & 66.43 & 61.15 & 63.81 & 66.70 & 76.03 & 64.20 \\
$\mathrm{Ni}$ & 53 & 56 & 53 & 47 & 56 & 57 & 55 \\
$\mathrm{Co}$ & 30 & 45 & 44 & 22 & 53 & 55 & 55 \\
$\mathrm{Mn}$ & 302 & 299 & 294 & 260 & 932 & 431 & 353 \\
$\mathrm{Cu}$ & 15 & 61 & 46 & 12 & 41 & 22 & 23 \\
$\mathrm{Ag}$ & 2 & 2 & 3 & 2 & 3 & 3 & 3 \\
$\mathrm{Bi}$ & 37 & 44 & 59 & 30 & 60 & 71 & 61 \\
$\mathrm{Cd}$ & 5 & 8 & 7 & 5 & 8 & 8 & 6 \\
$\mathrm{In}$ & 6 & 8 & 7 & 9 & 11 & 11 & 9 \\
\hline
\end{tabular}

Atomic absorption spectrometry. 

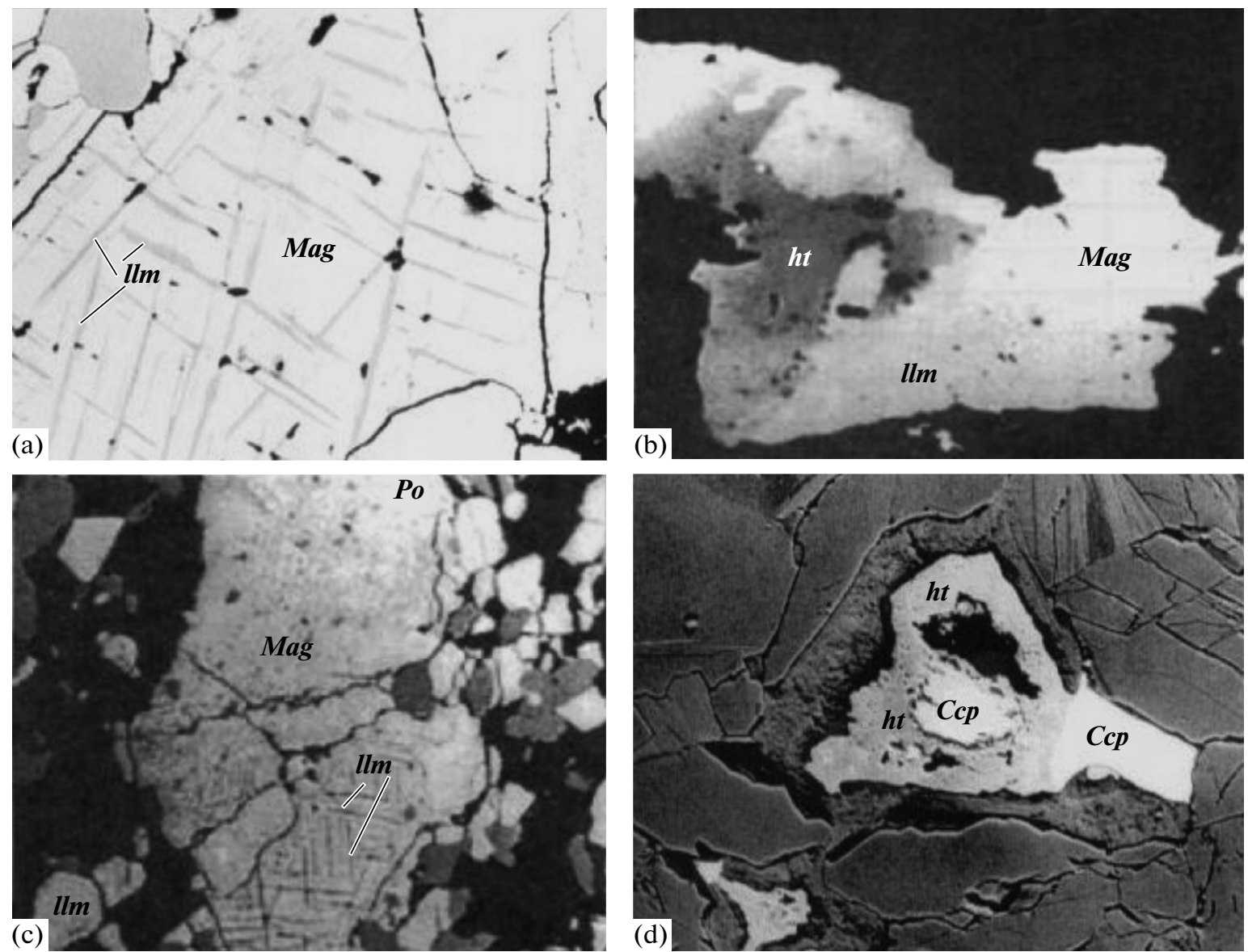

Fig. 6. Micro-scale morphology of major ore minerals from the Mitrashinci deposit.

(a), coarse magnetite grains ( $\mathrm{Mag}$, white) with ilmenite lamellae ( $\mathrm{Im}$, grey-white) in contact with ilmenite grain (dark grey), $100 \times$ magnification; (b), allotriomorphic ilmenite grain (grey) in contact with magnetite (white) and goethite ( $h t$, dark grey), $100 \times$ magnification; (c), magnetite (greyish white) with ilmenite exsolution lamellae (light grey), allotriomorphic ilmenite grains (grey) with drop-like pyrrhotite segregations (Po, white), 100× magnification; (d), goethite (grey) pseudomorphously replacing pyrite (grey-white) and hypidiomorphic chalcopyrite grain $(C c p$, white).

contents compared to other elements. The irregular distribution of trace elements in pyrite is probably explained by variations in the physicochemical conditions (temperature and composition of ore-bearing fluids) during crystallization.
Pyrrhotite is commonly present as two morphologically distinct varieties and its content does not exceed $1 \%$. Pyrrhotite most commonly occurs as drop-like inclusions in magnetite, ilmenite and some other ore minerals. The second variety of pyrrhotite forms hypidio-

Table 4. Quantitative electron microprobe data for magnetite and titanomagnetite from the Mitrashinci deposit (wt \%)

\begin{tabular}{|c|c|c|c|c|c|c|}
\hline Element & 1 & 2 & 3 & 4 & 5 & 6 \\
\hline $\mathrm{Fe}$ & 76.54 & 76.67 & 72.36 & 71.39 & 63.71 & 54.97 \\
\hline $\mathrm{Ti}$ & 0.05 & 0.36 & 0.14 & 0.34 & 8.06 & 13.53 \\
\hline Mn & - & - & 0.08 & 0.09 & 0.56 & 1.09 \\
\hline $\mathrm{Mg}$ & 0.27 & 0.18 & - & 0.25 & - & - \\
\hline $\mathrm{Al}$ & 0.59 & 0.43 & 0.34 & 0.53 & 0.30 & 0.33 \\
\hline $\mathrm{Ni}$ & 0.49 & 0.52 & 0.36 & 0.49 & 0.45 & 0.35 \\
\hline $\mathrm{Cr}$ & 0.04 & - & 0.03 & - & 0.06 & - \\
\hline $\mathrm{O}$ & 22.07 & 21.83 & 26.67 & 26.89 & 26.44 & 29.44 \\
\hline Total & 99.99 & 99.99 & 99.98 & 99.98 & 99.98 & 99.91 \\
\hline
\end{tabular}

Analyses 1-4 are magnetite, 5 and 6 are titanomagnetite. 
Table 5. Quantitative electron microprobe data ilmenite from the Mitrashinci deposit (wt \%)

\begin{tabular}{l|c|c|c|c|c}
\hline Element & 1 & 2 & 3 & 4 & 5 \\
\hline $\mathrm{Fe}$ & 34.64 & 33.95 & 36.71 & 35.38 & 35.08 \\
$\mathrm{Ti}$ & 27.58 & 29.57 & 29.67 & 28.68 & 29.44 \\
$\mathrm{Mn}$ & 1.74 & 2.21 & 2.05 & 2.07 & 1.97 \\
$\mathrm{Mg}$ & - & - & 0.29 & - & - \\
$\mathrm{Al}$ & 0.23 & 0.34 & 0.38 & 0.36 & 0.23 \\
$\mathrm{Ni}$ & 0.08 & 0.19 & 0.29 & 0.34 & 0.41 \\
$\mathrm{Cr}$ & - & - & - & 0.11 & 0.05 \\
$\mathrm{O}$ & 35.60 & 33.73 & 30.62 & 33.07 & 32.80 \\
Total & 99.88 & 99.99 & 100.01 & 100.01 & 99.98 \\
\hline
\end{tabular}

morphic and, more rarely, allotriomorphic grains, probably representing low-temperature pyrrhotite, which differs greatly in its morphology and chemical composition from the drop-like pyrrhotite variety (Table 7). Table 7 shows that the Fe content ranges from 61 to $61.9 \%$ in the drop-like pyrrhotite and is about $58 \%$ in the low-temperature variety. The latter also contains minor amounts of $\mathrm{Ni}$ and $\mathrm{Cu}$, and rarely As.

Chalcopyrite is a common mineral, and its content in the ore does not exceed $0.3 \%$. Unlike pyrrhotite, it forms allotriomorphic and, more rarely, hypidiomorphic grains and occurs sometime as isolated grains in association with pyrite and pyrrhotite. As seen in Table 7, the chemical composition of chalcopyrite is fairly close to the theoretical one. Chalcopyrite also contains small amounts of $\mathrm{Ni}$.
Goethite is a common secondary mineral. It occurs as fracture-fill or pseudomorphs after pyrite (Fig. 6d). The proportion of goethite in the ore may reach $3-5 \%$.

Other ore minerals are present in insignificant amounts, forming microscopic segregations. Detailed analysis of these minerals requires large-volume samples.

\section{ORE TEXTURE AND STRUCTURE}

Macroscopic examination of polished sections revealed three well-marked varieties of structure: massive, disseminated, and banded-ore layered structure.

Disseminated structure is characterized by a nonuniform distribution of dispersed grains and aggregates of ore minerals in the rock matrix. This structure is typical of amphibole schists with nonuniformly distributed magnetite grains of a regular shape (about $2 \mathrm{~mm}$ across). The disseminated structure is also present in ore bodies as disseminated grains of major and accessory ore minerals.

A massive structure is exhibited by nonporous aggregates of the different ore minerals, which occur as continuous and regular intergrowths. This structure is more often observed in the amphibolites than in the amphibolite schists (Fig. 7a).

A banded or layered structure is less commonly perceptible in the ore bodies with massive magnetitetitanomagnetite mineralization and schist grains. The individual layers may vary from $2 \mathrm{~mm}$ in size (Fig. 7b).

Cumulative texture. Microscopic examination of the ore aggregates revealed several types of cumulative textures. In these textures, grains of silicate minerals have a general idiomorphic/hypidiomorphic or rounded shape and the voids between them are filled with allotriomorphic granular $\mathrm{Fe}-\mathrm{Ti}$ oxides (Fig. 8a). The characteristic feature is the combination of

Table 6. Trace element composition of pyrite from the Mitrashinci deposit (ppm)

\begin{tabular}{l|c|c|c|c|c|r|r}
\hline \multicolumn{1}{c|}{ Element } & 1 & 2 & 3 & 4 & 5 & 6 & 7 \\
\hline $\mathrm{Fe} \%$ & 45.47 & 44.63 & 44.72 & 45.10 & 44.51 & 43.51 & 44.30 \\
$\mathrm{Ni}$ & 1140 & 110 & 63 & 255 & 112 & 1050 & 1180 \\
$\mathrm{Co}$ & 940 & 530 & 720 & 540 & 410 & 850 & 980 \\
$\mathrm{Mn}$ & 74 & 121 & 112 & 103 & 102 & 32 & 31 \\
$\mathrm{Cu}$ & 1100 & 1260 & 580 & 2760 & 224 & 6410 & 3890 \\
$\mathrm{Bi}$ & 58 & 53 & 46 & 56 & 90 & 60 & 53 \\
$\mathrm{Ag}$ & 6 & 4 & 5 & 5 & 8 & 2 & 5 \\
$\mathrm{Cd}$ & 16 & 12 & 12 & 7 & 12 & 8 & 7 \\
$\mathrm{In}$ & 8 & 9 & 8 & 7 & 10 & 8 & 9 \\
\hline
\end{tabular}

Atomic absorption spectrometry. 
Table 7. Quantitative electron microprobe data for pyrrhotite from the Mitrashinci deposit (wt \%)

\begin{tabular}{l|c|c|c|c|c|c}
\hline \multicolumn{1}{c|}{ Element } & 1 & 2 & 3 & 4 & 5 & 6 \\
\hline $\mathrm{Fe}$ & 61.98 & 61.02 & 58.16 & 58.44 & 33.35 & 31.04 \\
$\mathrm{Ti}$ & - & - & - & - & - & - \\
$\mathrm{Mn}$ & 0.10 & - & - & - & - & - \\
$\mathrm{Al}$ & - & - & - & - & - & - \\
$\mathrm{Cr}$ & 0.14 & 0.15 & 0.11 & 0.08 & 0.12 & 0.07 \\
$\mathrm{Ni}$ & 0.14 & 0.15 & 0.11 & 0.08 & 0.12 & 0.07 \\
$\mathrm{Cu}$ & 0.30 & - & 0.29 & 0.21 & 30.16 & 33.05 \\
$\mathrm{As}$ & - & - & 0.32 & - & - & - \\
$\mathrm{S}$ & 37.48 & 38.82 & 40.99 & 41.27 & 36.26 & 35.84 \\
Total & 100.00 & 99.99 & 100.00 & 100.00 & 99.89 & 100.00 \\
\hline
\end{tabular}

Analyses 1-4 are pyrrhotite ( 3 and 4 are low-temperature varieties) 5 and 6 are chalcopyrite.

medium and coarse granular textures (allotriomorphic granular and hypidiomorphic granular) (Fig. 8).

Lamellar (exsolution) textures represent aggregates of variously sized goethite lamellae oriented along planes within the titanomagnetite. In addition to thin lamellae (Fig. 6a), titanomagnetite also contains large, irregularly distributed ilmenite lamellae (Fig. 8b).

Corrosion textures. The following morphological varieties were identified in ores: cellular, skeletal (relic) and pseudomorphic (Fig. 6d, Fig. 8c). The most common cellular texture is formed by the replacement of magnetite by finely acicular hematite crystals along cleavage directions (Fig. 8c). Skeletal textures are found in titanomagnetite (Fig. 8b), while pseudomorphic textures are typical of goethite commonly replacing pyrite (Fig. 6d).

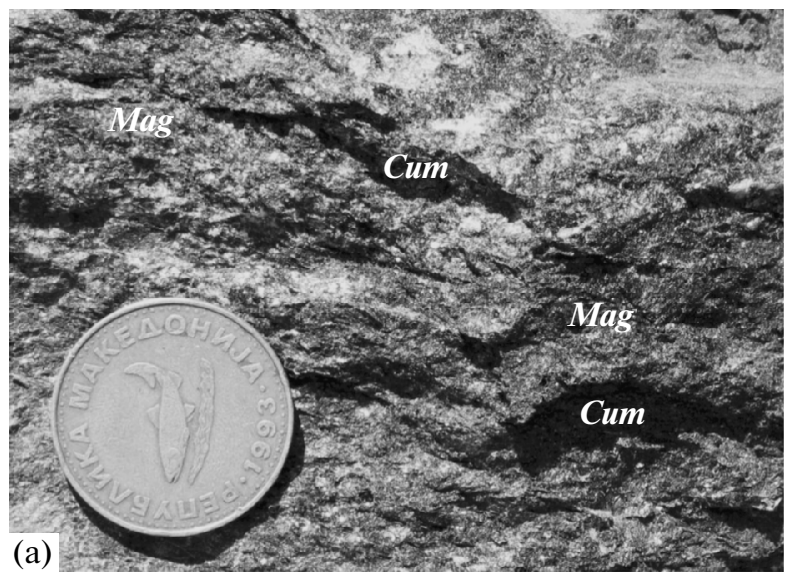

Cataclastic textures are found in hematite, pyrite, and goethite, which infill fractures and voids in rocks resulting from deformation (Fig. 8d). These minerals are formed by redeposition of ore material as a result of metamorphism.

Therefore, structural and textural observations are indicative of the magmatic and metamorphic origin of the ores.

\section{CONCLUSIONS}

Geological mapping within the SMM revealed several stratigraphic horizons of amphibolites, which are composed of barren garnet-biotite and mineralized garnet-cummingtonite amphibolites.

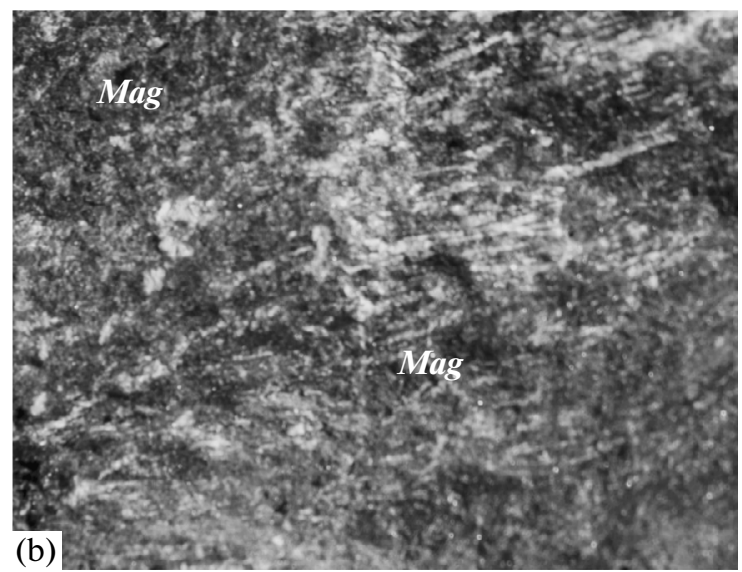

Fig. 7. Massive (a) and layered (b) structures of the ore from Mitrashinci deposit (see text). Mag, magnetite, Cum, cummingtonite. 

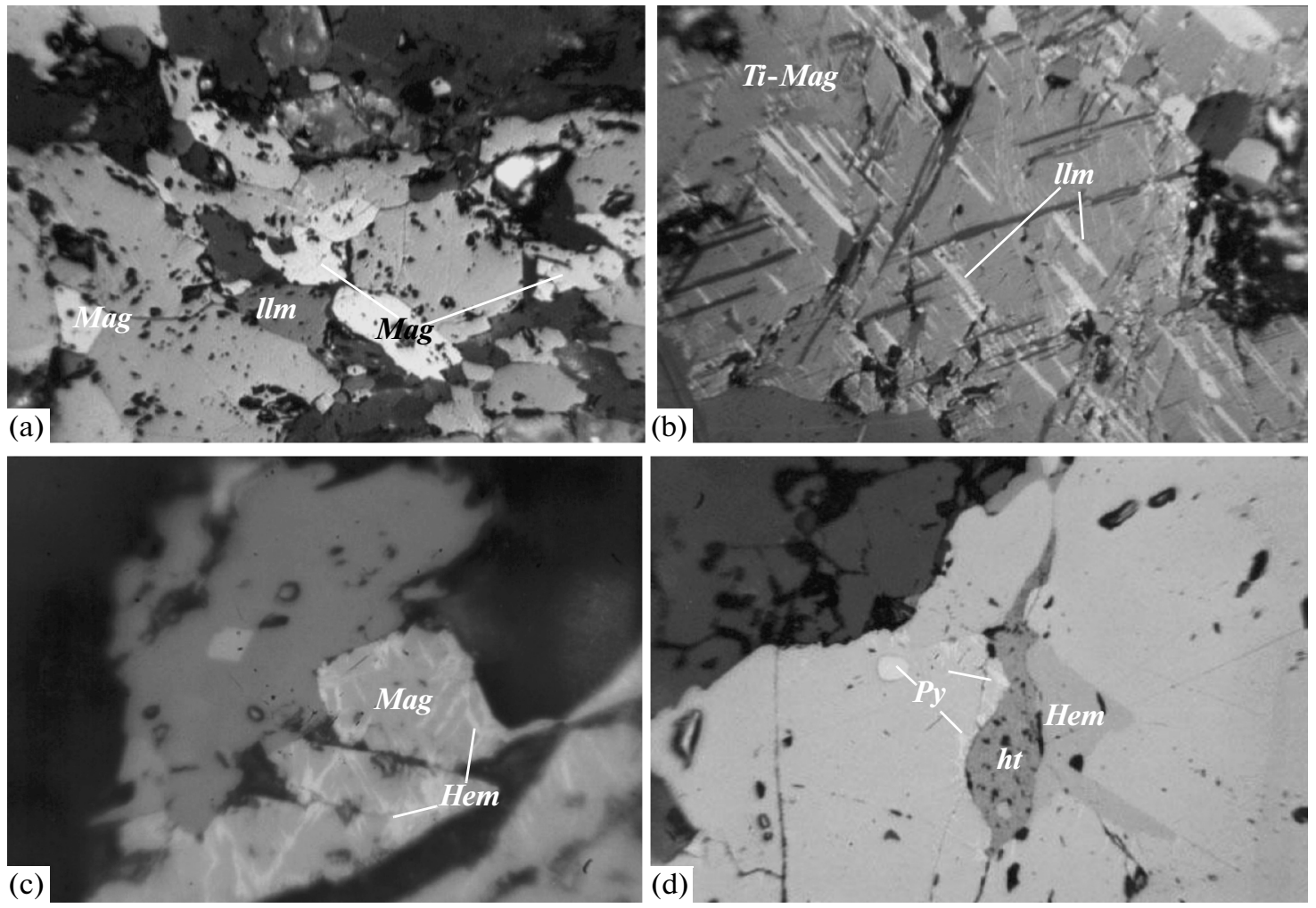

Fig. 8. Ore textures at the Mitrashinci deposit (see text), 100× magnification. (a), allotriomorphic granular and hypidiomorphic granular (granulte) textures; (b), lamellar exsolution texture (large ilmenite lamellae in the titanomagnetite); (c), cellular texture (magnetite is replaced by acicular hematite along cleavage planes); (d), cataclastic texture (see text). Py, pyrite, Hem, hematite.

$\mathrm{Fe}-\mathrm{Ti}$ oxide mineralization at Mitrashinci is hosted by the deeply buried amphibolites. The mineralized zone (varying in thickness from 20 to $300 \mathrm{~m}$ ) has been traced for $12 \mathrm{~km}$ within amphibolite host rocks. Several lens-like ore bodies hosted by garnet-cummingtonite amphibolites striking NW-SE were intersected by mining operations at Kobilski Rid, Gromadna, Leskovica, Dolga Poljana, and Bliznakov Cukar. The contents of Fe and Ti vary greatly in the ores $(13-23 \%$ and $4-9.1 \%$, respectively). The ore bodies consist mainly of $\mathrm{Fe}-\mathrm{Ti}$ oxides, such as magnetite, titanomagnetite, ilmenite, and hematite (martite), and are characterized by strong similarities in their morphological, petrographic, mineralogical, and geochemical features.

The major ore minerals (ilmenite, titanomagnetite, and magnetite with a minor sulfide phase) were formed during the magmatic phase of ore deposition and were not considerably affected by subsequent polyphase metamorphism.

Based on the results of this study, the Mitrashinci deposit can be classified as a metamorphosed type of $\mathrm{Fe}-\mathrm{Ti}$ oxide deposit. Note that amphibolites of the Precambrian shields and cratonic terranes of Russia can be regarded as primary targets in search for the metamorphosed types of $\mathrm{Fe}-\mathrm{Ti}$ deposits.

\section{REFERENCES}

Dumurdzanov, N., Serafimovski, T., and Burchfiel, B.C., Cenozoic tectonics of Macedonia and its relation to the south Balkan extensional regime, Geosphere, 2005, no. 1, pp. 1-22.

Dumurxanov, N., Zavrsen izvestaj zageoloskoto kartirawe na titano-jeleznite pojavivo regionotna Mitrasinci-Berovskovo 1976 god, Skopje: Str. fond na Geoloski zavod, 1977.

Dumurxanov, N., Zavrsen izvestaj zageoloskoto kartirawe na titano-jeleznite pojavivo regionotna Mitrasinci-Berovskovo 1977 god, Skopje: Str. fond na Geoloski zavod, 1978.

Dumurxanov, N., Jasmakovski, B., Ivanova, V., and Ivanov, T., Bazien magmatiza mimineralizaci javo Srpsko-Makedonski ot masivvo SR. Makedonija, Zbornikradova IX kongres nageolozite na Jugoslavija, Sarajevo, 1978, pp. 477-482.

Ivanov, T., Izvestaj zageoloskite istra uvawana Ti-mineralizaci jakajseloto Mitrasinci, Skopje: Str. fond na Tehnolosko-metalurski Fakultet, 1975.

Jovanovis, D. and Kuvenxiski, T., Godisen izvestaj zaistra niterabotinale isteto so éleznirudi MitrasinciBerovskovo 1976 god, Skopje: Str. fond na Geoloski zavod, 1977.

Jovanovis, D. and Kuvenxiski, T., Izvestaj zaizvrseniteistranirabotivo regionot Mitrasinci-Berovsko vo period ot od 1977 do 1979 god, Skopje: Str. fond na Geoloski zavod, 1980.

Mircovski, V., Boev, B., and Spasovski, O., The amphibolite rocks south-west of the village of Mitrasinci, the Serbo- 
Macedonian massif, Republic of Macedonia, Terranes of Serbia, Belgrade, 1996, pp. 173-178.

Petkovski, P., Izvestaj zaizvrsenite kompleksni geoloski istra nirabotina proekt ot A. 2. Rudni ot reon: Delcevo-Pehcevo-Berovovo, 1996 god, Skopje: Str. fond na OP "Geoinstitut", 1997.

Serafimovski, T. and Spasovski, O., Sastav nekih rudnih minerala titanomagentitskih orudnjavanja kod s. Mitrasinci, XXVI Oktobarsko Savetovanje Rudara i Metalurga, 1994, pp. 31-34.

Simic, M. and Simic, V., Mineralne facije u metamorfnoj seriji zelenih skrilaca na planini plackovici, SR Makedonija, in Trudovi na Geoloskiot Zavod na SRM, 1957.

Simic, M. and Simic, V., Mineralne facije u metamorfnoj seriji zelenih skriqaca na planini Plaskovici, SR Mekedonija, in Trudovi na Geoliskizavodna SRM, 1963.

Spasovski, O., Metalogenijarudne zone Mitrasinci Istona Makedonija, Magistarskateza, Beograd, 1993.

Spasovski, O., Occurences of Fe-Ti mineralization in the vicinity of village of Mitrasinci, Geologica Macedonica, 1994, no. 8 , pp. $45-51$.
Spasovski, O. and Serafimovski, T., Lezista i pojave titanomagnetita u Srpsko-Makedonskom masivu na teritoriji Republike Makedonije, XIII Kongres Geologa Jugoslavije, Herceg Novi, 1998, vol. IV, pp. 809-826.

Spasovski, O., Tipogenetski karakteristiki na titanomagnetitite od Republika Makedonija, Doktorska disertacija, Rudarsko-geoloski fakultet Stip, 2001.

Spasovski, O., Chemical and geochemical characteristics of the major minerals in the ore deposit Mitrasinci (Eastern Macedonia), Geologica Macedonica, 2004, no. 20, pp. 1-7.

Stojanov, R., Zagorchev, I., Dumurdzanov, N., and Aleksandrov, M., Paleozoic Correlation in the Broder Area of Macedonia and SW Bulgaria, in Symposium Annual Meeting, Proceedings, Dojran, 1997, pp. 209-214.

Zagorchev, I. and Moorbath, S., Problems of the metamorphism in Central Rhodope Mountains in the light of $\mathrm{Rb}-\mathrm{Sr}$ isotope data, Geologica Balcanica, 1986, vol. 16, no. 6, pp. $31-37$.

Translated by N. Kravets 